\title{
EVALUATION OF POLLUTANT LOADING IN THE RUNOFF WATERS FROM A MAJOR URBAN HIGHWAY (GDANSK BELTWAY, POLAND)
}

\author{
Ż. POLKOWSKA ${ }^{1, *}$ \\ K. SKARŻYŃSKA ${ }^{1}$ \\ A. DUBIELLA-JACKOWSKA ${ }^{1}$ \\ W. STASZEK ${ }^{2}$ \\ J. NAMIEŚNIK ${ }^{1}$
}

Received: 22/11/06

Accepted: 02/04/07

\author{
${ }^{1}$ Gdańsk University of Technology, Chemical Faculty \\ 11/12 G. Narutowicza St., 80-952 Gdańsk, Poland \\ ${ }^{2}$ University of Gdańsk, Faculty of Physical Geography \\ and Environmental Protection \\ 16a R. Dmowskiego St., 80-246 Gdańsk, Poland
}

*to whom all correspondence should be addressed: e-mail: zaneta@chem.pg.gda.pl

\begin{abstract}
Runoff water is an important medium transporting various air pollutants from the air to the surface water. This paper presents the results of measurement of removal rates of anions and cations in the rain, road runoff, throughfall and surface water near a major urban highway (Gdańsk beltway). The results were subjected to statistical evaluation. Analysis of the correlations between ions occurring in different forms of wet deposition and surface water confirmed a significant impact of the average daily traffic and seasonal variations.
\end{abstract}

KEYWORDS: road runoff water; rain; throughfall; surface water; anions; cations; heavy metals

\section{INTRODUCTION}

Increased paved surfaces and human activity in urban areas result in an increased amount of pollutants accumulated. The origin and quantity of pollutants found in highway runoff are site specific and depend on a number of factors, including traffic, highway maintenance, normal depositions on the highway and spillages. Highway surface types (asphalt or concrete) seem to have a minimal effect on the runoff quality (Hares and Ward, 1999).

Rain water washes dusts away from the atmosphere and the impervious urban surfaces and, in the form of road runoff, carries off dissolved, colloidal and solid constituents in a heterogeneous mixture, which includes organic and inorganic compounds, nutrients, oils, greases and heavy metals (Hares and Ward, 1999; Barbosa and Hvitved-Jacobsen, 1999; Pagotto et al., 2000; Legret and Pagotto, 1999; Gnecco et al., 2005; Hewitt and Rashed, 1992). The contaminant may remain permanently on the surface, may be removed from the road by resuspension or may be removed in the road runoff waters. The road runoff itself seems to play an important role, both as a pollutant source and a pollutant sorbent (Mangani et al., 2005).

The study presented in this paper is an evaluation of the contamination of roads with heavy traffic in a big urban agglomeration (Gdańsk beltway) with selected important organic and inorganic compounds, which are quite often carcinogenic and mutagenic. With regard to the pollutants in rain, road runoff water, throughfall and surface waters (near highway) the following groups of compounds are identified: heavy metals in the dissolved form $(\mathrm{Zn}, \mathrm{Pb})$, anions $\left(\mathrm{F}^{-}, \mathrm{Br}^{-}, \mathrm{Cl}^{-}, \mathrm{SO}_{4}{ }^{2-}, \mathrm{NO}_{2}^{-}, \mathrm{NO}_{3}^{-}, \mathrm{PO}_{4}{ }^{3-}\right)$ and cations $\left(\mathrm{K}^{+}, \mathrm{Na}^{+}, \mathrm{Ca}^{2+}, \mathrm{Mg}^{2+}, \mathrm{NH}_{4}^{+}\right)$. The choice of sampling site allowed the effects of vehicles on the atmospheric water quality to be determined without interference from other pollution sources. The study also provides detailed information on the correlations of concentration of cations and anions with the same parameters commonly monitored in rain, runoff, throughfall and surface waters. This paper focuses on the seasonal variability of $\mathrm{Cl}^{-}$in all forms of atmospheric and surface water (up to $200 \mathrm{~m}$ from the road). 


\section{METHODS}

\subsection{Sampling}

Samples of rain, throughfall, surface and road runoff waters from major highways were collected from January 2005 to December 2005 at eight sites with heavy traffic located along a major transportation route - Gdańsk beltway. Table 1 summarizes general characteristics of the sampling sites.

Table 1. Characteristics of sampling sites

\begin{tabular}{|c|c|c|c|c|}
\hline $\begin{array}{l}\text { Sampling } \\
\text { site }\end{array}$ & Longitude & Latitude & $\begin{array}{l}\text { Short description of the site, } \\
\text { distance from Gdańsk beltway }\end{array}$ & Type of sample \\
\hline OP1 & $18^{\circ} 29^{\prime} 34^{\prime \prime} \mathrm{E}$ & $54^{\circ} 26^{\prime} 36^{\prime \prime} \mathrm{N}$ & $\begin{array}{l}\text { Gdańsk Gołębiewo, } \\
\text { open area, } 30 \mathrm{~m}\end{array}$ & rain \\
\hline OP2 & $18^{\circ} 29^{\prime} 27^{\prime \prime} \mathrm{E}$ & $54^{\circ} 26^{\prime} 33^{\prime \prime} \mathrm{N}$ & $\begin{array}{c}\text { Gdańsk Gołębiewo, } \\
\text { areas of woodland, } 30 \mathrm{~m}\end{array}$ & throughfall \\
\hline S1 & $18^{\circ} 29^{\prime} 26^{\prime \prime} \mathrm{E}$ & $54^{\circ} 26^{\prime} 36^{\prime \prime} \mathrm{N}$ & \multirow{3}{*}{$\begin{array}{l}\text { Gdańsk beltway, } \\
\text { near Gdańsk Gołębiewo }\end{array}$} & \multirow{3}{*}{ road runoff } \\
\hline S2 & $18^{\circ} 29^{\prime} 29^{\prime \prime} \mathrm{E}$ & $54^{\circ} 26^{\prime} 48^{\prime \prime} \mathrm{N}$ & & \\
\hline S3 & $18^{\circ} 29^{\prime} 31^{\prime \prime E}$ & $54^{\circ} 26^{\prime} 48^{\prime \prime} \mathrm{N}$ & & \\
\hline Z1 & $18^{\circ} 29^{\prime} 27^{\prime \prime E}$ & $54^{\circ} 26^{\prime} 37^{\prime \prime} \mathrm{N}$ & \multirow{6}{*}{$\begin{array}{l}\text { Gdańsk, Gdynia, areas of } \\
\text { woodland, } 5-200 \mathrm{~m}\end{array}$} & \multirow{6}{*}{$\begin{array}{l}\text { surface } \\
\text { water }\end{array}$} \\
\hline Z2 & $18^{\circ} 29^{\prime} 40^{\prime \prime} \mathrm{E}$ & $54^{\circ} 26^{\prime} 54^{\prime \prime} \mathrm{N}$ & & \\
\hline Z3 & $18^{\circ} 30^{\prime} 00^{\prime \prime} \mathrm{E}$ & $54^{\circ} 27^{\prime} 01^{\prime \prime} \mathrm{N}$ & & \\
\hline Z4 & $18^{\circ} 29^{\prime} 59^{\prime \prime} \mathrm{E}$ & $54^{\circ} 26^{\prime} 54^{\prime \prime} \mathrm{N}$ & & \\
\hline Z5 & $18^{\circ} 29^{\prime} 50^{\prime \prime} \mathrm{E}$ & $54^{\circ} 27^{\prime} 21^{\prime \prime} \mathrm{N}$ & & \\
\hline Z6 & $18^{\circ} 28^{\prime} 50^{\prime \prime} \mathrm{E}$ & $54^{\circ} 27^{\prime} 56^{\prime \prime} \mathrm{N}$ & & \\
\hline
\end{tabular}

\subsection{Analytical methods}

Samples were collected during or immediately after a precipitation event. They were stored at low temperatures without any chemical preservatives because the analysis was performed either directly on-site or immediately after the samples were delivered to the laboratory. Runoff samples were usually highly contaminated with solids (sand, leaves); therefore, they had to be pre-filtered. The analytical techniques used in this study are summarized in Table 2 .

Table 2. Operating conditions of the analytical techniques used in the study (quantified against synthetic rain standards (RAIN-97, CRM 409) [Polkowska et al., 2002]

\begin{tabular}{|c|c|c|c|c|}
\hline Analyte & Technique & Analytical parameters & $\begin{array}{l}\text { Limit of } \\
\text { detection }\end{array}$ & $\begin{array}{c}\text { Precision } \\
\text { [\% RSD] }\end{array}$ \\
\hline $\begin{array}{l}\text { Anions/ } \\
\text { Cations }\end{array}$ & $\begin{array}{c}\text { Ion } \\
\text { chromatography IC }\end{array}$ & $\begin{array}{c}\text { Conductivity detection, } \\
\text { AutoSuppression Recycle Mode } \\
\text { ASRC }^{\circledR} \text {-ULTRA/ CSRS }{ }^{\circledR} \text {-ULTRA, } \\
\text { AS9-HC/ CS12A column }\end{array}$ & $0.001 \mathrm{meq} \mathrm{I}^{-1}$ & 1 \\
\hline Metals & $\begin{array}{l}\text { Atomic Absorption } \\
\text { Spectroscopy } \\
\text { (AAS) }\end{array}$ & $\begin{array}{l}\text { AAS, BUCK Scientific model } 210- \\
\text { VGP Graphite furnace, BUCK } \\
\text { Scientific model 220-GF }\end{array}$ & $0.01 \mu$ eq $I^{-1}$ & 2 \\
\hline
\end{tabular}

\section{RESULTS AND DISCUSSION}

Various quality parameters can be measured in highway runoff, depending on the objectives of the study. The pollutants specifically related to the traffic are heavy metals, oil and grease, and hydrocarbons. The heavy metals most commonly detected in runoff water are lead $(\mathrm{Pb})$ and zinc (Zn). Chlorides are also important for the roads where deicing salts are applied. Nutrients (nitrogen and phosphorus) may result from the contribution of fertilized soils, and coliforms from animal refuse.

The research (104 samples analyzed, 1203 determinations performed) has resulted in the acquisition of a large number of data regarding the content of selected analytes in rain, throughfall, road runoff and surface waters. Detailed distributions of various species (anions, cations) are shown in Figure $1 a$ and $b$. The highest concentrations were observed for chloride, sulfate and sodium in samples from road runoff. 
(a)

(b)
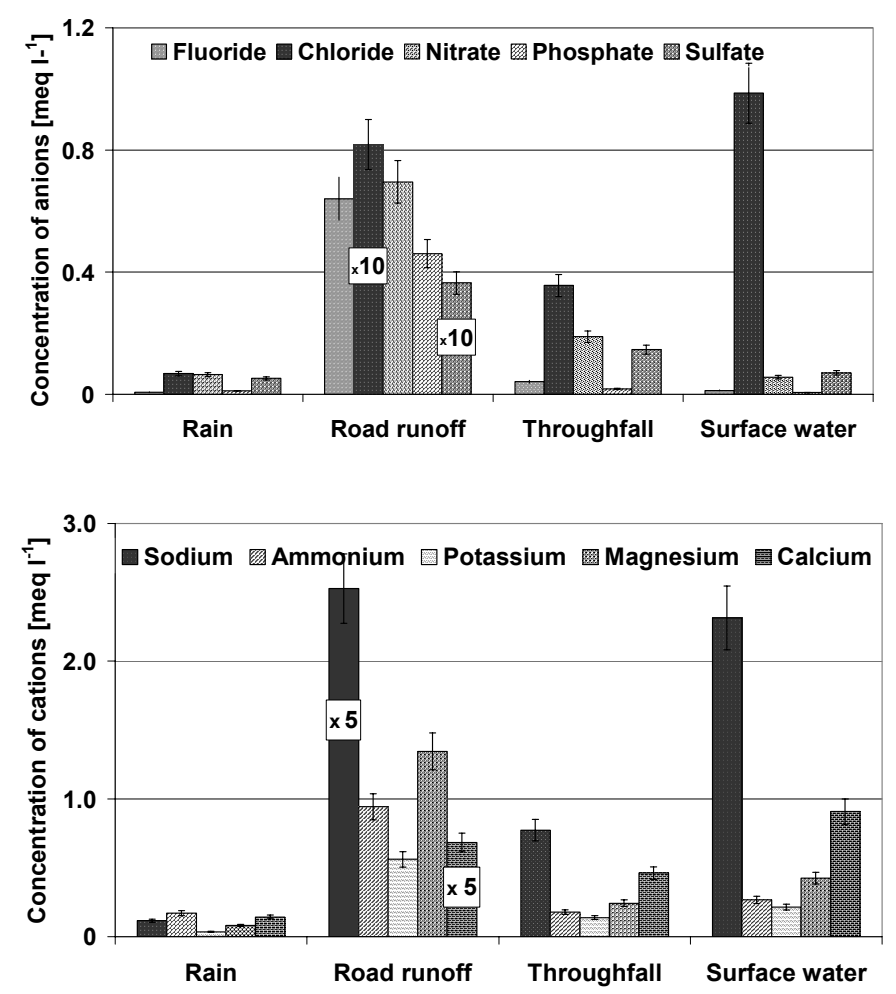

Figure 1. Average concentrations of anions $(A)$ and cations $(B)$ in various atmospheric and surface waters

\subsection{Heavy metals}

Among heavy metals, $\mathrm{Zn}$ and $\mathrm{Pb}$ exhibited the highest concentrations, as expected for typical pollutants associated with vehicular traffic (Hares and Ward, 1999; Gnecco et al., 2005). The highest heavy metal concentrations were found in road runoff water and throughfall (see Figure 2). The main source of lead is fuel. However, it appears that only $5 \%$ of the lead is removed by runoff water. The largest fraction may, therefore, disperse in the atmosphere or settle on the soil by the roadside. A relatively high level of $\mathrm{Zn}$ could be explained by the existence of metallic guardrails. According to Hewitt and Rashed (1992), the main sources of zinc are wear and tear from tires and brakes and from the corrosion of galvanized safety barriers, or from an alternative material (Barbosa and Hvitved-Jacobsen, 1999). As for $\mathrm{Pb}$ and $\mathrm{Zn}$, concentrations increase in winter because of the use of chloride-based deicing salts, which generate supply and corrosion phenomena.

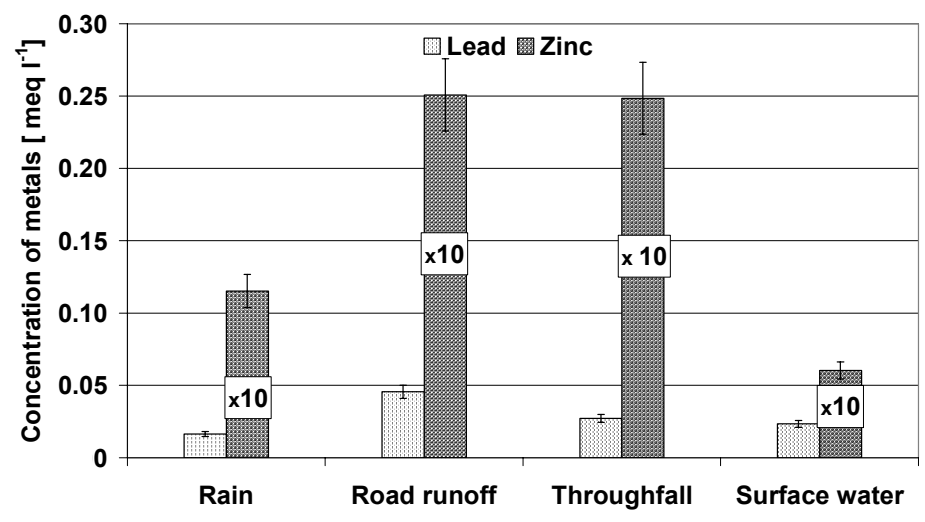

Figure 2. Average concentrations of lead and zinc in various atmospheric and surface waters 


\subsection{Direct Correlation between Pollutant Concentrations and Average Daily Traffic (ADT)}

The pollution load in highway runoff depends on the average daily traffic, air quality and rainfall intensity and duration (Hvitved-Jacobsen et al., 1994). Traffic volume would seem to be an important factor for predicting runoff quality. Prior to storm events, roadways with ADT greater than 30,000 vehicles may produce runoff with two to five times the runoff pollutant levels found in that from rural highways. However, this highway runoff may not directly impact receiving streams. This is true for both ADT and the number of vehicles during a storm. Naturally occurring surface winds and vehicular caused turbulence remove significant amounts of pollutants from road surfaces. These wind effects, therefore, lessen the impact traffic volumes have on runoff loadings to streams (Kayhanian et al., 2003).

Simple linear regression analysis was performed to evaluate a direct correlation between ADT and the concentration of highway runoff pollutants (see Figure 3 ). The results of this analysis revealed relatively high $R$ values (ranging from 0.49 to 0.70 ) for all constituents, which may suggest a direct correlation between ADT and pollutant concentrations. However, most of the studies reported in the literature did not confirm strong correlations. For example, Chui et al. (1982) found only a weak correlation, and a study conducted by Driscoll et al. (1990) suggested that there is no strong and definitive relationship between differences in traffic density and the pollutant concentrations for a site. Other investigators found somewhat better correlations between ADT and highway runoff pollutants. For example, McKenzie and Irwin (1983) found that the concentrations of lead and zinc correlate well with ADT.

\subsection{Ionic correlations}

Correlation coefficients between various components of rain and road runoff were calculated for all events. The results, in the form of correlation matrices for ion pairs, are presented in Table 3. Very strong correlations between ions in wet deposition (correlation coefficients greater than 0.95) were found in 6 cases for rain and 5 cases for road runoff. Nitrate, sulfate and chloride ions were correlated most probably because their precursors, $\mathrm{SO}_{2}, \mathrm{NO}_{x}$ and $\mathrm{Cl}_{2}$, are often co-emitted, and because they behave similarly in rain. For rain, the correlations between sodium, potassium, magnesium and calcium with chloride and nitrate were most likely related to reactions of atmospheric acids $\left(\mathrm{HNO}_{3}\right.$ and $\left.\mathrm{HCl}\right)$ with alkaline species present in the atmosphere. In road runoff, a strong positive correlation existed only for sodium and calcium with chloride and nitrate.

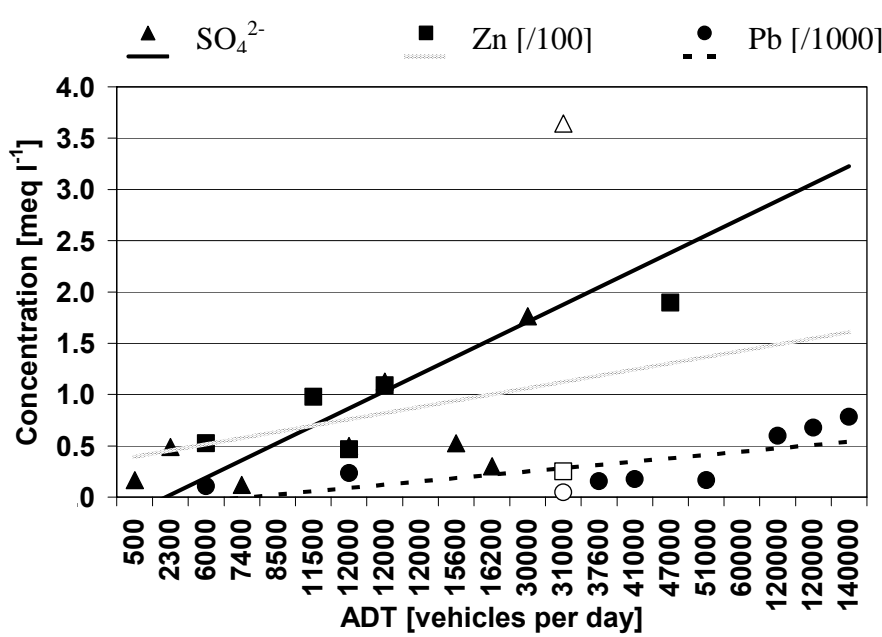

Figure 3. Dependence of the average concentration of selected pollutants on the ADT (from literature data: Hares and Ward, 1999; Barbosa and Hvitved-Jacobsen, 1999; Pagotto et al., 2000; Legret and Pagotto, 1999; Hewitt and Rashed, 1992;

Harrison and Wilson, 1985; Bäckström et al., 2003; Dannecker et al., 1990; CH2MHILL with McNamee et al., 1998; Stotz, 1987 and this work - open point) 
Table 3. Ion pair correlations

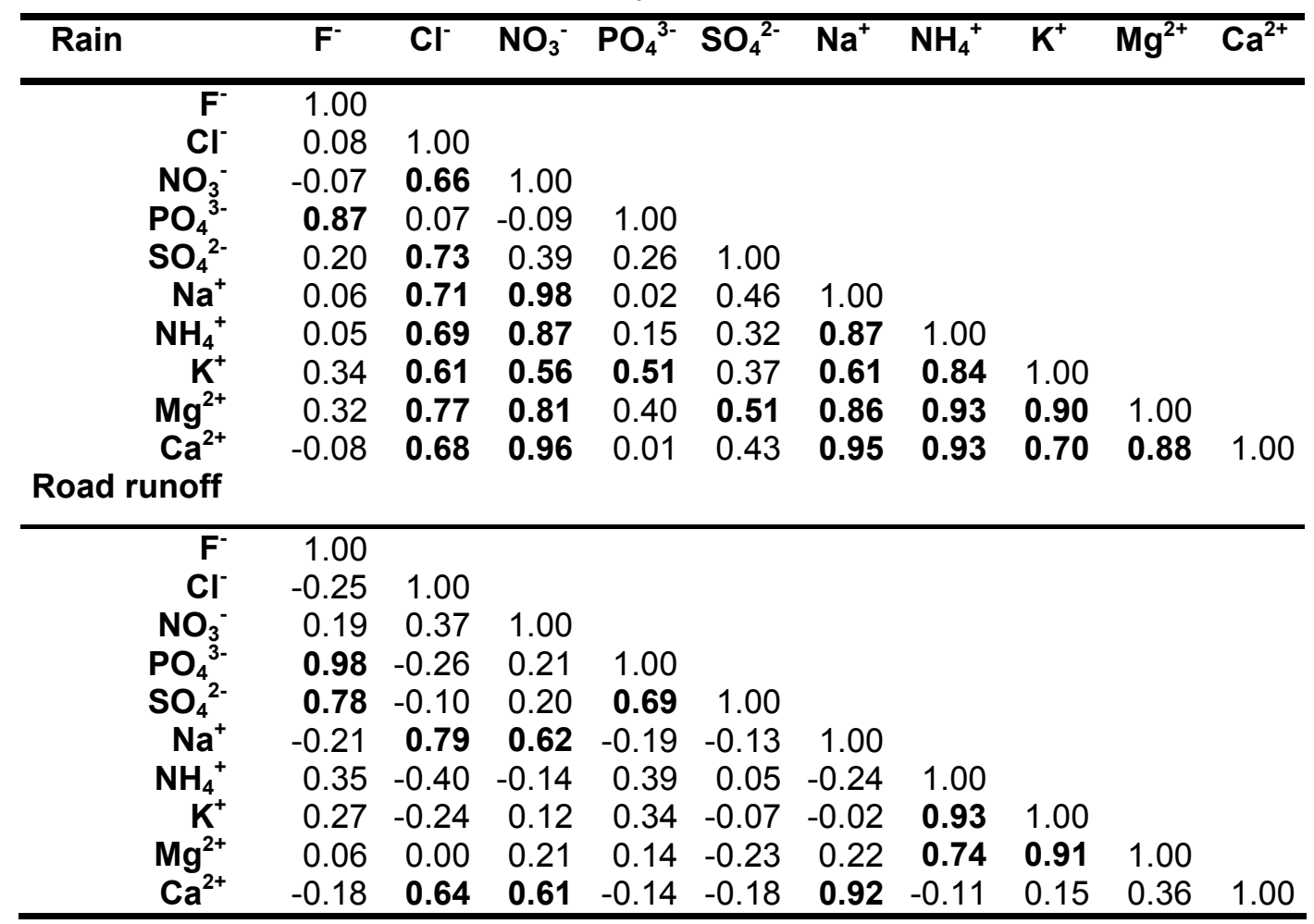

Correlations between chloride, nitrate and sulfate on the one hand, and the ammonium, sodium, potassium and calcium cations on the other, indicate that the acidity in precipitation is neutralized. The neutralizing action was further confirmed by establishing correlations between anion and cation combinations as shown in Table 4.

lonic ratios in rain water were similar to those observed for throughfall and surface water. However, ionic ratios in road runoff were completely different (impact of a major rural highway). The values of the correlation coefficient were positive (and higher than 0.5 ) for41 (50) in rain, 28 (50) in throughfall, 37 (50) in surface water and only 7 (50) in road runoff.

\subsection{Seasonal variations in water quality}

Seasonal variations in rain, road runoff, throughfall and surface water quality have been studied, with special attention to the concentration of chloride (see Figure 4). Winter (or early spring) time salting and sanding practices, for example, may result in higher concentrations of chloride, sodium and calcium on the roadway surface.

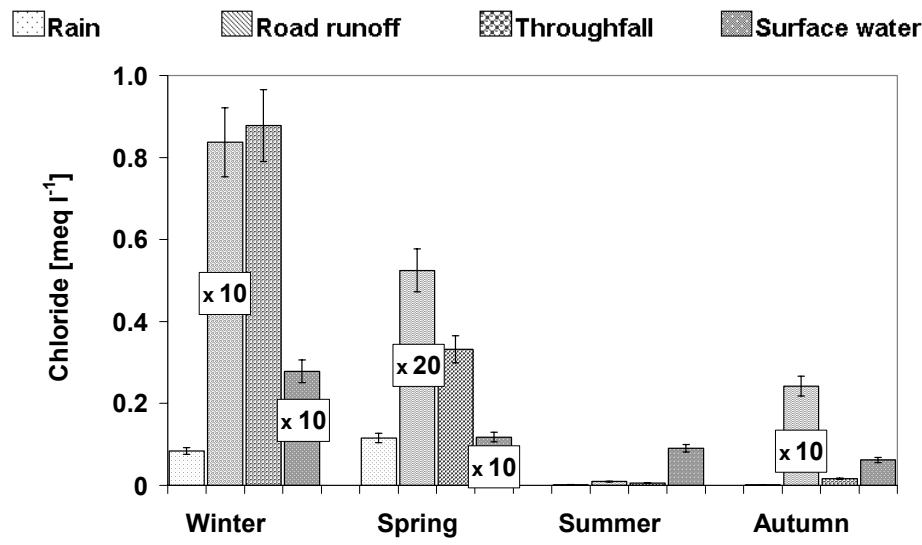

Figure 4. Seasonal variations of chloride concentration in various forms of atmospheric and surface water 
Table 4. Correlation coefficients for anion/cation combinations

\begin{tabular}{|c|c|c|c|c|c|}
\hline Rain & $\mathrm{Cl}^{-}$ & $\mathrm{NO}_{3}^{-}$ & $\mathrm{SO}_{4}{ }^{2-}$ & $\mathrm{NO}_{3}{ }^{-}+\mathrm{SO}_{4}{ }^{2-}$ & $\mathrm{Cl}^{-}+\mathrm{NO}_{3}{ }^{-}+\mathrm{SO}_{4}{ }^{2-}$ \\
\hline $\mathrm{Na}^{+}$ & $\overline{0.71}$ & 0.98 & 0.46 & 0.97 & 0.94 \\
\hline $\mathrm{NH}_{4}^{+}$ & 0.69 & 0.87 & 0.32 & 0.83 & 0.83 \\
\hline $\mathrm{K}^{+}$ & 0.61 & 0.56 & 0.37 & 0.59 & 0.62 \\
\hline $\mathrm{Mg}^{2+}$ & 0.77 & 0.81 & 0.51 & 0.84 & 0.86 \\
\hline $\mathrm{Ca}^{2+}$ & 0.68 & 0.96 & 0.43 & 0.94 & 0.91 \\
\hline $\mathrm{Ca}^{2+}+\mathrm{Mg}^{2+}$ & 0.73 & 0.94 & 0.47 & 0.94 & 0.92 \\
\hline $\mathrm{Ca}^{2+}+\mathrm{Mg}^{2+}+\mathrm{K}^{+}$ & 0.73 & 0.92 & 0.47 & 0.92 & 0.91 \\
\hline $\mathrm{Ca}^{2+}+\mathrm{Mg}^{2+}+\mathrm{K}^{+}+\mathrm{NH}_{4}^{+}$ & 0.73 & 0.91 & 0.42 & 0.90 & 0.89 \\
\hline $\mathrm{K}^{+}+\mathrm{NH}_{4}^{+}$ & 0.69 & 0.84 & 0.33 & 0.81 & 0.81 \\
\hline $\mathrm{Ca}^{2+}+\mathrm{Mg}^{2+}+\mathrm{NH}_{4}^{+}$ & 0.72 & 0.93 & 0.42 & 0.91 & 0.90 \\
\hline \multicolumn{6}{|l|}{ Road runoff } \\
\hline $\mathrm{Na}^{+}$ & 0.79 & 0.62 & -0.13 & -0.04 & 0.62 \\
\hline $\mathrm{NH}_{4}^{+}$ & -0.40 & -0.14 & 0.05 & 0.03 & -0.31 \\
\hline $\mathrm{K}^{+}$ & -0.24 & 0.12 & -0.07 & -0.05 & -0.23 \\
\hline $\mathrm{Mg}^{2+}$ & 0.00 & 0.21 & -0.23 & -0.20 & -0.13 \\
\hline $\mathrm{Ca}^{2+}$ & 0.64 & 0.61 & -0.18 & -0.09 & 0.47 \\
\hline $\mathrm{Ca}^{2+}+\mathrm{Mg}^{2+}$ & 0.47 & 0.54 & -0.24 & -0.16 & 0.28 \\
\hline $\mathrm{Ca}^{2+}+\mathrm{Mg}^{2+}+\mathrm{K}^{+}$ & 0.41 & 0.52 & -0.23 & -0.15 & 0.24 \\
\hline $\mathrm{Ca}^{2+}+\mathrm{Mg}^{2+}+\mathrm{K}^{+}+\mathrm{NH}_{4}^{+}$ & 0.24 & 0.42 & -0.19 & -0.13 & 0.12 \\
\hline $\mathrm{K}^{+}+\mathrm{NH}_{4}^{+}$ & -0.37 & -0.07 & 0.02 & 0.01 & -0.29 \\
\hline $\mathrm{Ca}^{2+}+\mathrm{Mg}^{2+}+\mathrm{NH}_{4}^{+}$ & 0.29 & 0.44 & -0.20 & -0.13 & 0.16 \\
\hline \multicolumn{6}{|l|}{ Throughfall } \\
\hline $\mathrm{Na}^{+}$ & 0.76 & 0.26 & 0.86 & 0.54 & 0.72 \\
\hline $\mathrm{NH}_{4}^{+}$ & -0.07 & 0.60 & -0.09 & 0.48 & 0.21 \\
\hline $\mathrm{K}^{+}$ & 0.68 & 0.33 & 0.53 & 0.48 & 0.64 \\
\hline $\mathrm{Mg}^{2+}$ & 0.43 & 0.76 & 0.29 & 0.76 & 0.65 \\
\hline $\mathrm{Ca}^{2+}$ & 0.45 & 0.76 & 0.43 & 0.82 & 0.69 \\
\hline $\mathrm{Ca}^{2+}+\mathrm{Mg}^{2+}$ & 0.45 & 0.78 & 0.39 & 0.81 & 0.69 \\
\hline $\mathrm{Ca}^{2+}+\mathrm{Mg}^{2+}+\mathrm{K}^{+}$ & 0.49 & 0.76 & 0.42 & 0.81 & 0.71 \\
\hline $\mathrm{Ca}^{2+}+\mathrm{Mg}^{2+}+\mathrm{K}^{+}+\mathrm{NH}_{4}^{+}$ & 0.41 & 0.83 & 0.34 & 0.84 & 0.68 \\
\hline $\mathrm{K}^{+}+\mathrm{NH}_{4}^{+}$ & 0.14 & 0.64 & 0.07 & 0.58 & 0.39 \\
\hline $\mathrm{Ca}^{2+}+\mathrm{Mg}^{2+}+\mathrm{NH}_{4}^{+}$ & 0.37 & 0.84 & 0.31 & 0.84 & 0.66 \\
\hline \multicolumn{6}{|l|}{ Surface water } \\
\hline $\mathrm{Na}^{+}$ & 0.47 & 0.47 & 0.92 & 0.86 & 0.54 \\
\hline $\mathrm{NH}_{4}^{+}$ & 0.44 & 0.48 & 0.89 & 0.84 & 0.51 \\
\hline $\mathrm{K}^{+}$ & 0.53 & 0.67 & 0.87 & 0.90 & 0.60 \\
\hline $\mathrm{Mg}^{2+}$ & 0.61 & 0.49 & 0.88 & 0.84 & 0.67 \\
\hline $\mathrm{Ca}^{2+}$ & 0.79 & 0.17 & 0.36 & 0.33 & 0.78 \\
\hline $\mathrm{Ca}^{2+}+\mathrm{Mg}^{2+}$ & 0.79 & 0.33 & 0.62 & 0.59 & 0.81 \\
\hline $\mathrm{Ca}^{2+}+\mathrm{Mg}^{2+}+\mathrm{K}^{+}$ & 0.78 & 0.40 & 0.69 & 0.67 & 0.81 \\
\hline $\mathrm{Ca}^{2+}+\mathrm{Mg}^{2+}+\mathrm{K}^{+}+\mathrm{NH}_{4}^{+}$ & 0.73 & 0.45 & 0.78 & 0.75 & 0.77 \\
\hline $\mathrm{K}^{+}+\mathrm{NH}_{4}^{+}$ & 0.49 & 0.56 & 0.91 & 0.89 & 0.56 \\
\hline $\mathrm{Ca}^{2+}+\mathrm{Mg}^{2+}+\mathrm{NH}_{4}^{+}$ & 0.74 & 0.40 & 0.75 & 0.71 & 0.77 \\
\hline
\end{tabular}

\section{CONCLUSION}

Road runoff is an important source of potentially toxic contaminants in fresh waters. The runoff from Gdansk's beltway was also contaminated with a number of pollutants, the concentrations of which were generally similar to those reported in previous studies (Gnecco et al., 2005). Motorway pavement runoff water contains a large quantity of organic and inorganic compounds and of heavy metals. This pollution is increased during the period when deicing salts are used. During the winter, antifreeze salts are a source of not only sodium, calcium, and chlorine but also of high zinc levels, as a result of enhancement of corrosion phenomena due to the heavy metal mobilizing effects of deicing solutions containing sodium chloride and calcium chloride (Mangani et al., 2005). 
High traffic intensity on the Gdańsk beltway, related to commercial transport and a dynamic growth of the private car sector, was most probably responsible for high concentrations of various forms of contaminants in the vicinity of major highways. However, no significant correlation could be found between pollutant levels in road runoff water and all the remaining types of water. Much higher pollution of runoff water is probably caused by some factors other than the atmospheric input.

In summary, therefore, the results of this study indicate that the quality of all atmospheric and surface waters was affected at stations located a short distance $(<200 \mathrm{~m})$ from point-source inputs of road runoff.

\section{ACKNOWLEDGEMENTS}

This scientific work was financially supported from for science in $2006-2008$ years as a research project (1T09D 098 30).

\section{REFERENCES}

Bäckström M., Nilsson U., Häkansson K., Allard B. and Karlsson S. (2003) Speciation of heavy metals in road runoff and roadside total deposition, Water, Air, Soil Pollut., 147, 343-366.

Barbosa A.E. and Hvitved-Jacobsen T. (1999) Highway runoff and potential for removal of heavy metals in an infiltration pond in Portugal, Sci. Total Environ., 235, 151-159.

CH2MHILL with McNamee, Porter ans Seeley, Inc (1998) Highway Stormwater Runoff Study, Prepared for The Michigan Department of Transportation.

Chui T. W., Mar B.W. and Horner R.R. (1982) Pollutant loading model for highway runoff, J. Environ. Eng., 108, 1193-1210.

Dannecker W., Au M. and Stechmann H. (1990) Substance load in rainwater runoff different streets in Hamburg, Sci. Total Environ., 93, 385-392.

Driscoll E.D., Shelley P.E. and Strecker E.W. (1990) Pollutant loadings and impacts from highway stormwater runoff. Volume III: Analytical investigation and research report. Publication No. FHWA-RD-88-008, Federal Highway Administration, Washington, D.C.

Gnecco I., Berretta C., Lanza L.G. and La-Barbera P. (2005) Storm water pollution in the urban environment of Genoa, Italy, Atmos. Res., 77, 60-73.

Hares R.J. and Ward N.I. (1999) Comparison of the heavy metal content of motorway stormwater following discharge into wet biofiltration and dry detention ponds along the London Orbital (M25) motorway, Sci. Total Environ., 235, 169-178.

Harrison R.M. and Wilson S.J. (1985) The chemical composition of highway drainage waters I. major ions and selected trace metals, Sci. Total Environ., 43, 63-77.

Hewitt C.N. and Rashed M.B. (1992) Removal rates of selected pollutants in the runoff waters from a major rural highway, Water Resolution, 26, 311-319.

Hvitved-Jacobsen T., Johansen N.B. and Yousel Y.A. (1994) Treatment systems for urban and highway run-off in Denmark, Sci. Total Environ., 146/147, 499-506.

Kayhanian M., Singh A., Suverkropp C. and Borroum S. (2003) Impact of Annual Average Daily Traffic on Highway Runoff Pollutant Concentrations, J. Environ. Eng., 129, 975-990.

Legret M. and Pagotto C. (1999) Evaluation of pollutant loadings in the runoff waters from a major rural highway, Sci. Total Environ., 235, 143-150.

Mangani G., Berloni A., Bellucci F., Tatano F. and Maione M. (2005) Evaluation of the pollutant content in road runoff first flush waters, Water, Air, Soil Pollut., 160, 213-228.

McKenzie D.J. and Irwin G.A. (1983) Water-quality assessment of stormwater runoff from a heavily used urban highway bridge in Miami, Florida, Report No. 83-4153, USGS, Water Resources Investigations, Menlo Park, Calif.

Pagotto C., Legret M. and Le-Cloirec P. (2000) Comparison of the hydraulic behaviour and the quality of highway runoff water according to the type of pavement, Water Resolution, 34, 4446-4454.

Polkowska Ż, Astel A., Grynkiewicz M., Górecki T. and Namieśnik J. (2002) Studies on intercorrelation between ions co-occurring in precipitation in the Gdańsk-Sopot-Gdynia Tricity (Poland), J. Atmos. Chem., 41, 239-264.

Stotz G. (1987) Investigations of the properties of the surface water run-off from federal highways in the FRG, Sci. Total Environ., 59, 329-337. 
